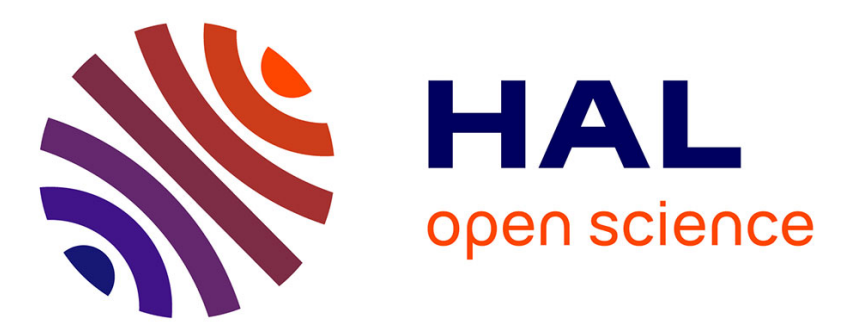

\title{
Taxonomic and functional prokaryote diversity in mildly arsenic-contaminated sediments
}

David Halter, Audrey Cordi, Simonetta Gribaldo, Sébastien Gallien, Florence Goulhen-Chollet, Audrey Heinrich-Salmeron, Christine Carapito, Christophe Pagnout, Didier Montaut, Fabienne Seby, et al.

\section{To cite this version:}

David Halter, Audrey Cordi, Simonetta Gribaldo, Sébastien Gallien, Florence Goulhen-Chollet, et al.. Taxonomic and functional prokaryote diversity in mildly arsenic-contaminated sediments. Research in Microbiology, 2011, 162 (9), pp.877-887. 10.1016/j.resmic.2011.06.001 . pasteur-02445836

\section{HAL Id: pasteur-02445836 \\ https://hal-pasteur.archives-ouvertes.fr/pasteur-02445836}

Submitted on 13 Mar 2020

HAL is a multi-disciplinary open access archive for the deposit and dissemination of scientific research documents, whether they are published or not. The documents may come from teaching and research institutions in France or abroad, or from public or private research centers.
L'archive ouverte pluridisciplinaire HAL, est destinée au dépôt et à la diffusion de documents scientifiques de niveau recherche, publiés ou non, émanant des établissements d'enseignement et de recherche français ou étrangers, des laboratoires publics ou privés.

$$
\text { Copyright }
$$




\title{
Taxonomic and functional prokaryote diversity in mildly arsenic-contaminated sediments
}

\author{
David Halter ${ }^{\mathrm{a}}$, Audrey Cordi ${ }^{\mathrm{b}}$, Simonetta Gribaldo ${ }^{\mathrm{c}}$, Sébastien Gallien ${ }^{\mathrm{d}}$, \\ Florence Goulhen-Chollet ${ }^{\mathrm{a}}$, Audrey Heinrich-Salmeron ${ }^{\mathrm{a}}$, Christine Carapito ${ }^{\mathrm{d}}$, \\ Christophe Pagnout ${ }^{\mathrm{b}}$, Didier Montaut ${ }^{\mathrm{e}}$, Fabienne Seby ${ }^{\mathrm{e}}$, Alain Van Dorsselaer ${ }^{\mathrm{d}}$, \\ Christine Schaeffer ${ }^{\mathrm{d}}$, Philippe N. Bertin ${ }^{\mathrm{a}}$, Pascale Bauda ${ }^{\mathrm{b}}$, Florence Arsène-Ploetze ${ }^{\mathrm{a}, *}$ \\ ${ }^{a}$ Laboratoire de Génétique Moléculaire, Génomique, Microbiologie, Département Microorganismes, Génomes, Environnement, UMR7156 Université de \\ Strasbourg/CNRS, 28 rue Goethe, 67083 Strasbourg Cedex, France \\ ${ }^{\mathrm{b}}$ Laboratoire des Interactions Ecotoxicologie Biodiversité Ecosystèmes (LIEBE), UMR7146, CNRS, Université Paul Verlaine, Campus Bridoux, \\ rue du Général Delestraint, 57070 Metz, France \\ ${ }^{\mathrm{c}}$ Institut Pasteur, Département de Microbiologie, Unité de Biologie Moléculaire chez les Extrêmophiles (BMGE), 5, rue du Docteur \\ Roux 75724 Paris cedex 15, France \\ ${ }^{\mathrm{d}}$ Laboratoire de Spectrométrie de Masse Bio-organique, Institut Pluridisciplinaire Hubert Curien, UMR7178 Université de Strasbourg/CNRS, \\ 25 rue Becquerel, 67087 Strasbourg, France \\ ${ }^{\mathrm{e}}$ Laboratoire Ultra-Traces Analyse Aquitaine, Hélioparc Pau-Pyrénées, 2 avenue du Président Angot, 64053 Pau cedex 9, France
}

Received 13 October 2010; accepted 9 May 2011

Available online 13 June 2011

\begin{abstract}
Arsenic-resistant prokaryote diversity is far from being exhaustively explored. In this study, the arsenic-adapted prokaryotic community present in a moderately arsenic-contaminated site near Sainte-Marie-aux-Mines (France) was characterized, using metaproteomic and 16S rRNA-encoding gene amplification. High prokaryotic diversity was observed, with a majority of Proteobacteria, Acidobacteria and Bacteroidetes, and a large archaeal community comprising Euryarchaeaota and Thaumarchaeota. Metaproteomic analysis revealed that Proteobacteria, Planctomycetes and Cyanobacteria are among the active bacteria in this ecosystem. Taken together, these results highlight the unsuspected high diversity of the arsenic-adapted prokaryotic community, with some phyla never having been described in highly arsenic-exposed sites.

(C) 2011 Institut Pasteur. Published by Elsevier Masson SAS. All rights reserved.
\end{abstract}

Keywords: Environmental genomics; Arsenic; Mining; Biodiversity; Metaproteomics

\footnotetext{
* Corresponding author.

E-mail addresses: David.halter@gem.u-strasbg.fr (D. Halter), Audrey. cordi@umail.univ-metz.fr (A. Cordi), simonetta.gribaldo@pasteur.fr (S. Gribaldo), sgallien@chimie.u-strasbg.fr (S. Gallien), Florence.Chollet@gem. u-strasbg.fr (F. Goulhen-Chollet), audrey.salmeron@gem.u-strasbg.fr (A Heinrich-Salmeron), ccarapito@chimie.u-strasbg.fr (C. Carapito), pagnout@ univ-metz.fr (C. Pagnout), didier.montaut@univ-pau.fr (D. Montaut), fabienne.seby@univ-pau.fr (F. Seby), vandors@chimie.u-strasbg.fr (A. Van Dorsselaer), cschaeff@chimie.u-strasbg.fr (C. Schaeffer), philippe.bertin@ unistra.fr (P.N. Bertin), bauda@univ-metz.fr (P. Bauda), ploetze@unistra.fr (F. Arsène-Ploetze).
}

\section{Introduction}

Arsenic is distributed ubiquitously throughout the world: its abundance on earth is around $1.5-3 \mathrm{mg} \mathrm{kg}^{-1}$ and it is the 20th most abundant element. Arsenic levels present in soil and sediments usually range from 0.1 to $50 \mathrm{mg} \mathrm{kg}^{-1}$, giving a mean value of 5-6 $\mathrm{mg} \mathrm{kg}^{-1}$ (Mandal and Suzuki, 2002). Arsenic concentrations present in soils and sediments actually vary considerably from one geographical region to another depending on the geochemical characteristics of the soil. For example, arsenic contents have been reported to range from 10 to $196 \mathrm{mg} \mathrm{kg}^{-1}$ in West Bengali sediments (India), from 0.01 
to $626 \mathrm{mg} \mathrm{kg}^{-1}$ in soil and sediments from China and from 1 to $72 \mathrm{mg} \mathrm{kg}^{-1}$ in soil originating from the United States (Mandal and Suzuki, 2002). High levels of arsenic can be due either to natural contamination by the parent rock (India) or human activities (anthropogenic forms of contamination) (Mandal and Suzuki, 2002). In natural waters, less than $10 \mu \mathrm{g}^{-1}$ is usually present, but arsenic levels of $5000 \mu \mathrm{g} \mathrm{l^{-1 }}$ have been observed in contaminated waters in the USA, South America, India and Bangladesh (Smedley and Kinniburgh, 2002). Arsenic-rich waters occur naturally in geothermal regions or because of the geochemical characteristics of the soils. Anthropogenic contaminations are observed principally in mining regions due to acid mine drainages (AMDs) efflux characterized by high sulfate, iron and other metal concentrations (Coupland et al., 2004; Hallberg and Johnson, 2005). In these aquatic environments, arsenic occurs mainly in the form of the inorganic species arsenate $(\mathrm{As}(\mathrm{V}))$ and arsenite (As(III)), which are generally more toxic than the organic forms to living organisms (Sharma and Sohn, 2009). As(III) is more soluble, and usually thought to be more toxic than $\operatorname{As}(\mathrm{V})$.

Several studies have shown that bacterial metabolic processes such as arsenic oxidation and reduction play an important role in arsenic speciation in the environment and affect its biodisponibility (Lièvremont et al., 2009). However, knowledge available about arsenic-resistant bacteria was restricted until quite recently to results of studies on bacteria grown in vitro (Lièvremont et al., 2009; Tsai et al., 2009). To explore the diversity of arsenic-metabolizing prokaryotes, several laboratories have developed environmental genomic approaches such as meta-genomic, meta-transciptomic and meta-proteomic approaches (Bertin et al., 2008; Denef et al., 2010). Functional studies have been performed on highly arsenic-contaminated AMDs (VerBerkmoes et al., 2009; Denef et al., 2010; Mueller et al., 2010; Bruneel et al., in press). However, arsenic-tolerant prokaryote diversity is far from being explored, since most of those previous studies focused on highly contaminated sites or on AMD-exposed sites which combine several abiotic stresses such as low $\mathrm{pH}$ and high heavy metals concentration, where a low level of bacterial diversity was observed.

The aim of this study was to further investigate arsenicadapted prokaryote diversity. For this purpose, a study site located in the vicinity of the Gabe-Gottes mine, which was worked until 1940 in the Sainte-Marie-aux-Mines Valley (France), was chosen (Fig. 1). The material extracted initially consisted of silver ore and, more recently, of arsenic ore. Currently, waters are percolating from the mine walls and accumulate in a creek. Preliminary experiments showed that the arsenic present in the creek sediments amounts to about $500 \mathrm{mg} \mathrm{kg}{ }^{-1}$, which constitutes a moderate but significant level of contamination. In this study, the physical and chemical characteristics of this site, the microbial community inhabiting the creek sediments and the main proteins expressed were analyzed using environmental genomic/proteomic approaches.

\section{Materials and methods}

\subsection{In situ sampling procedure and chemical analyses}

The sampling site was at a creek formed by the waters from a former mine located $40 \mathrm{~m}$ from the mine entrance, at

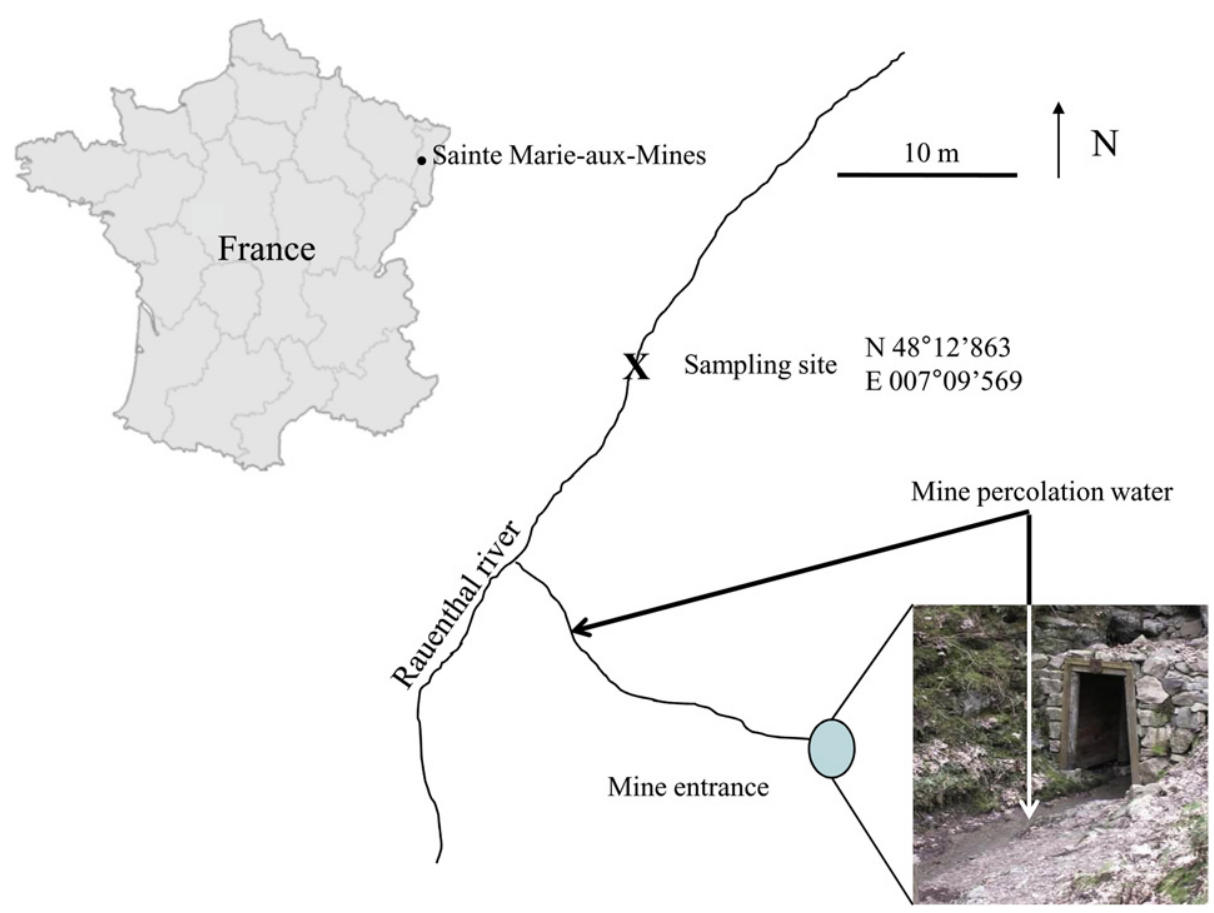

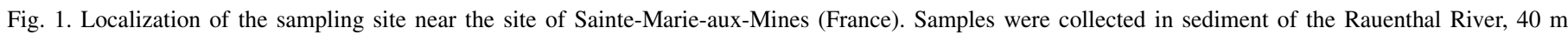
downstream from a mine entrance in waters percolating through the ancient mining exploitation. 
Sainte-Marie-aux-Mines in France (Fig. 1). One liter of water was filtered through a $0.22 \mu \mathrm{m}$ sterile nucleopore filter and stored at $4{ }^{\circ} \mathrm{C}$ for chemical analysis, which was performed within $48 \mathrm{~h}$. The $5 \mathrm{~cm}$ most superficial sediments from the creek were collected in December 2007 with a plastic shovel at several points along the creek and homogenized. After being sampled, water and sediments were separated, sediments were stored at $-80^{\circ} \mathrm{C}$ for DNA extraction or in glycerol $(25 \%$, $\mathrm{w} / \mathrm{v})$ at $-80{ }^{\circ} \mathrm{C}$ for protein extraction.

Water $\mathrm{pH}$ was measured using a microprocessor $\mathrm{pH}$ meter (pH 3000, WTW) and acid-neutralizing capacity (ANC) was determined using Gran's titration method. Conductivity was measured with a Metrohm Herisau Conductometer E518 (Herisau, Switzerland $)$ at $25{ }^{\circ} \mathrm{C}$. Mineralization of sediments $(0.5 \mathrm{~g}$ dry weight) was performed in line with the French standard AFNOR NFX 31-151 prior to performing metal analysis using atomic absorption spectrophotometry methods. Organic content was determined from the loss of mass determined after treatment at $550{ }^{\circ} \mathrm{C}$ for $4 \mathrm{~h}$. Metal and metalloid concentrations (after acidification with $\mathrm{HNO}_{3}$ ) were determined by performing atomic absorption spectrophotometry (Analyst 100; PerkinElmer and Varian SpectrAA-300) and $\mathrm{Br}^{-}, \mathrm{Cl}^{-}, \mathrm{SO}_{4}{ }^{2-}, \mathrm{NO}_{3}{ }^{-}$ and $\mathrm{NO}_{2}{ }^{-}$concentrations by performing ion chromatography (Dionex 1500 i with a AS 4 A SC column; Sunnyvale, CA, USA). The suspended solids content, total phosphorus (TP), total Kjeldahl nitrogen (TKN), COD (chemical oxygen demand), BOD5 (biological oxygen demand after 5 days), and TSS (total suspended solids) were determined according to French standards relating to water analysis (AFNOR, 1994). Total phosphorus was determined in keeping with the French norm AFNOR NF T90-023. Chlorophyllic pigments were quantified spectrophotometrically (Specord 205) at 750 and $755 \mathrm{~nm}$.

In order to analyze arsenic speciation in the interstitial water, part of the frozen sediment was centrifuged. The supernatant was collected, filtered $(0.45 \mu \mathrm{m})$ and further quantified using standard additions to prevent occurrence of matrix effects with an HPLC-ICP-MS apparatus (PerkinElmer SCIEX ELAN 6100 DRC, Concord, ON, Canada) fitted with a Meinhard nebulizer and a cyclonic spray chamber. Briefly, arsenic species were separated with an anion-exchange column PRPX-100 $(100 \mathrm{~mm} \times 4.1 \mathrm{~mm}$, Hamilton, Reno, NV, USA). Eluent was delivered online at a flow rate of $1 \mathrm{ml} \mathrm{min}^{-1}$ with a high performance liquid chromatography pump (DIONEX ICS 3000, Sunnyvale, CA, USA) coupled with the ICP-MS. Samples were injected using an autosampler (DIONEX AS50, Sunnyvale, CA, USA) through a $100 \mu \mathrm{l}$ PEEK injection loop attached to an injection valve. The outlet of the HPLC column was directly connected to the nebulizer of the ICP-MS via $20 \mathrm{~cm}$ of PEEK capillary tubing $(0.17 \mathrm{~mm}$ i.d.). Concentration values and uncertainties involved were calculated from values determined in duplicate. To measure arsenic species concentrations in sediments, some of the frozen samples were lyophilized and ground prior to the extraction process. Extractions were performed in duplicate. The extraction method used was adapted from (Thomas et al., 1997). $10 \mathrm{~mL}$ of $\mathrm{H}_{3} \mathrm{PO}_{4} 1 \mathrm{M}$ were added to $0.4 \mathrm{~g}$ of sample in a Teflon vessel. The mixture was heated with a closed microwave system (CEM model MARS, Charlotte, NC,
USA) at $120^{\circ} \mathrm{C}$ for $20 \mathrm{~min}$. The remaining solution was diluted to $50 \mathrm{ml}$ with ultrapure water and then analyzed by performing HPLC-ICP-MS.

\subsection{Metagenomic DNA extraction and 16S rRNA gene analysis of the whole community}

DNA was extracted directly from the sediment community using a PowerMax soil DNA isolation kit in line with the manufacturer's recommendations (MoBio Laboratories, Inc.), concentrated by precipitation in $2.5 \mathrm{v} / \mathrm{v} 100 \%$ ethanol and $0.1 \mathrm{v} / \mathrm{v}$ sodium acetate $(3 \mathrm{M}, \mathrm{pH} 5.6)$ and stored at $-20{ }^{\circ} \mathrm{C}$ until further processing.

$1.5 \mathrm{~kb}$ bacterial and $571 \mathrm{bp}$ archaeal $16 \mathrm{~S}$ rRNA-encoding genes were amplified using metagenomic DNA as a matrix and universal bacterial and archaeal primers W01/W02 (5'-AGAGTTTGATCMTGGCTC- ${ }^{\prime}$ and $5^{\prime}$-GNTACCTTGTTA CGACTT-3') and ARC344F/ARC915R (5'-ACGGGGYG CAGCAGGCGCGA-3' and, 5'-GTGCTCCCCCGCCAATTC CT-3'), respectively (Stahl and Amann, 1991; Raskin et al., 1994). All PCR reaction mixtures contained $50 \mathrm{ng}$ DNA template, $5 \mu \mathrm{l}$ PCR buffer (5 PRIME buffer $10 \times$ ), $1 \mu \mathrm{l}$ of deoxynucleotide mix (Mix 5 PRIME, $10 \mathrm{mM}$ of each dNTP) $0.2 \mathrm{mM}$ of each primer and 2.5 U Taq DNA polymerase (5 PRIME) in $50 \mu \mathrm{l}$ volume. Bacterial 16S rRNA gene PCR amplification reactions were carried out with a Mastercycler gradient (Eppendorf) with an initial denaturation step at $95{ }^{\circ} \mathrm{C}$ for $5 \mathrm{~min}$, followed by 35 cycles of denaturation $\left(40 \mathrm{~s}\right.$ at $95^{\circ} \mathrm{C}$ ), a $30 \mathrm{~s}$ annealing step at $52^{\circ} \mathrm{C}$, a 45 s elongation step at $68^{\circ} \mathrm{C}$ and a final $10 \mathrm{~min}$ denaturation step at $68{ }^{\circ} \mathrm{C}$. Archaeal $16 \mathrm{~S}$ rRNA gene cycling conditions consisted of a 5 min denaturation step at $94{ }^{\circ} \mathrm{C}$ followed by 35 denaturation cycles of $1 \mathrm{~min}$ at $94{ }^{\circ} \mathrm{C}$, a 1 min annealing step at $71-61^{\circ} \mathrm{C}$ with a $0.5^{\circ} \mathrm{C}$ decrement per cycle during the first 20 cycles and a 1 min elongation step at $72{ }^{\circ} \mathrm{C}$, followed by a final $10 \mathrm{~min}$ elongation step at $72{ }^{\circ} \mathrm{C}$.

The fragments obtained were cloned into plasmids $\mathrm{pCR}^{\circledR} 2.1$ using the $\mathrm{TOPO}^{\circledR}$ TA cloning kit in line with the manufacturer's recommendations (Invitrogen Laboratories). 240 clones containing bacterial 16S rRNA-encoding genes and 83 clones containing archaeal 16S rRNA encoding genes were sequenced using primers $\mathrm{ARC} 344 \mathrm{~F}$ and W01, respectively (Stahl and Amann, 1991; Raskin et al., 1994; Achour et al., 2007). Sequences harboring more than $600 \mathrm{bp}$ in the case of bacterial 16S rRNA genes and more than $300 \mathrm{bp}$ in that of achaeal 16S rRNA genes were used for phylogenetic analysis. Indeed, these sequences were compared with those in the GenBank database by performing BLAST searches (Altschul et al., 1997) and those in the RDP database by performing SEQ MATCH searches (Cole et al., 2009). Chimeras were checked using pintail online (Ashelford et al., 2005). Sequences that corresponded to chimera were removed for further analysis.

Archaeal 16S rRNA gene homologs were collected from the nr database at NCBI, using the BLAST program (Altschul et al., 1997) with default parameters. The same procedure was used on the environmental database at NCBI, using each clone as a seed in order to enrich the samples. Sequences were 
aligned using the Muscle program (Edgar, 2004) with default parameters. Based on preliminary phylogenetic trees, only a few sequences representative of archaeal diversity were selected, giving a dataset of 152 sequences for final analysis. For similarity search, 445 unambiguously aligned positions were selected. A maximum likelihood tree was obtained using the PhyML program (Guindon and Gascuel, 2003) with a GTR model, 4 evolutionary rates, a calculated proportion of invariant sites and calculated nucleotide frequencies (default parameters). Statistical likelihood at nodes was calculated via a likelihood-ratio test (Anisimova and Gascuel, 2006).

Partial prokaryotic sequences were aligned using ClustalW (Thompson et al., 2002) separately on bacterial and archaea samples, and the respective distance matrices were obtained using DNADIST from the PHYLIP package (http://evolution. genetics.washington.edu/phylip.html). The resulting matrices were fed into DOTUR (Schloss and Handelsman, 2005) in order to calculate the number of OTUs at $97 \%$ and $85 \%$ level. These percentage identities OTUs served for generating rarefaction curves (Fig. 2).

\subsection{Metaproteomic analyses}

In order to identify the main proteins expressed in situ by the sediment community, prokaryotic cells were recovered from sediment as follows: $8 \times 12.5 \mathrm{~g}$ of frozen sediment were washed with $8 \times 12.5 \mathrm{~mL}$ of salt solution $\left(0.15 \mathrm{~g} \mathrm{l}^{-1} \mathrm{Na}_{2} \mathrm{SO}_{4}, 0.45 \mathrm{~g} \mathrm{l}^{-1}\right.$ $\left(\mathrm{NH}_{4}\right)_{2} \mathrm{SO}_{4} \cdot 10 \mathrm{H}_{2} \mathrm{O}, 0.05 \mathrm{~g} \mathrm{l}^{-1} \mathrm{KCL}, 0.5 \mathrm{~g} \mathrm{l}^{-1} \mathrm{MgSO}_{4} \cdot 7 \mathrm{H}_{2} \mathrm{O}$, $\left.0.05 \mathrm{~g} \mathrm{l}^{-1} \mathrm{KH}_{2} \mathrm{PO}_{4}, 0.014 \mathrm{~g} \mathrm{l}^{-1} \mathrm{Ca}\left(\mathrm{NO}_{3}\right)_{2} \cdot 4 \mathrm{H}_{2} \mathrm{O}\right)$ and gently
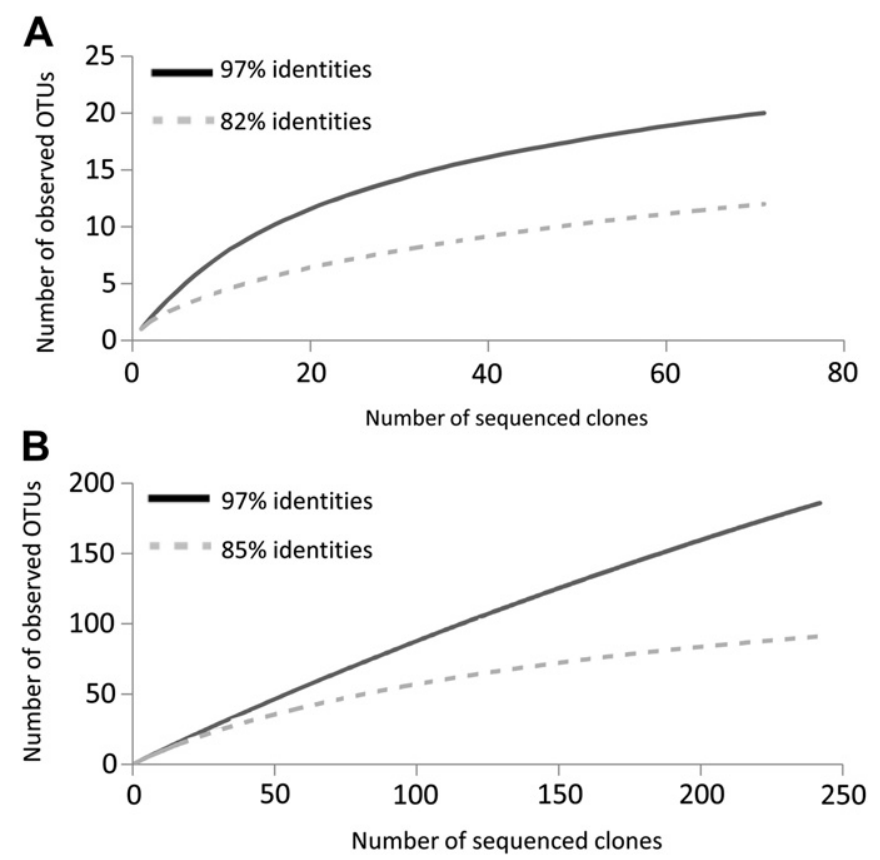

Fig. 2. Rarefaction analysis of the (A) archaeal 16S rRNA and (B) bacterial sequences from Sainte-Marie-aux-Mines sediments. The total number of sequenced clones is plotted against the number of OTUs observed in the same library. OTUs were defined at the $97 \%$ identity level (species level) for both and at $82 \%$ and $85 \%$ (class level) for Archaea and Bacteria, respectively. For archaeal analysis, the DOTUR program did not calculate the $85 \%$, but the $82 \%$ value. shaken overnight at $4{ }^{\circ} \mathrm{C}$. After a 30 min decantation step, the supernatant $(8 \times 7.5 \mathrm{ml})$ was added to Nycodenz solution without any mixing $(8 \times 17.5 \mathrm{~mL}, 65 \%$, w/v) (Axis-Shield, Dundee, Scotland), and centrifuged for $3 \mathrm{~h}$ at $10000 \mathrm{~g}$. The cellular fraction was removed and washed by adding 3 volumes of $\mathrm{NaCl} 0.9 \%$ and centrifuged for $1 \mathrm{~h}$ at $10000 \mathrm{~g}$ at $4{ }^{\circ} \mathrm{C}$. Cells were resuspended in $\mathrm{NaCl} 0.9 \%$ and an aliquot was stained using the LIVE/DEAD BacLight Bacterial Viability kit (L13152, Molecular Probes, Invitrogen) as recommended by the manufacturer, in order to assess the proportion of dead cells. The preparation was examined using an epifluorescent microscope Nikon Eclipse TE2000 S. Images were taken with an integrated Hamamatsu digital camera (C4742-95; Nikon UK).

Proteins were extracted from these cells and separated by 1D-SDS-PAGE using Laemmli's method (Laemmli, 1970) with a $12 \%$ gradient slab gel (PROTEAN II, Bio-Rad laboratories). Electrophoresis was carried out at 200 V. Proteins were stained with Coomassie Brilliant Blue, bands were systematically cut every $1.5 \mathrm{~mm}$ and the $29 \mathrm{gel}$ pieces were stored at $-20^{\circ} \mathrm{C}$ before performing mass spectrometry analysis.

In-gel digestion of gel bands was performed as previously described (Weiss et al., 2009). The resulting peptides were analyzed by nanoLC-MS/MS on nanoACQUITY UltraPerformance-LC (UPLC, Waters, Milford, MA, USA) coupled to an SYNAPT hybrid quadrupole orthogonal acceleration timeof-flight tandem mass spectrometer (Waters, Milford, MA, USA). The capillary voltage was set at $3500 \mathrm{~V}$ and the cone voltage at $35 \mathrm{~V}$. In tandem MS experiments, the system operated with automatic switching between MS and MS/MS modes. The 3 most abundant peptides, preferably doubly and triply charged ions, were selected from each MS spectrum for further isolation and CID fragmentation with 2 energies set using collision energy profile methods. The system was entirely controlled by MassLynx 4.1 (SCN 566, Waters, Milford, MA). Raw data collected during nanoLC-MS/MS analyses were processed and converted with a ProteinLynx Browser 2.3 (23, Waters, Milford, MA) into .pkl peak list format.

MS/MS data were analyzed using the MASCOT 2.2.0. algorithm (Matrix Science, London, UK). Spectra were searched for with a mass tolerance of $30 \mathrm{ppm}$ for MS and 0.1 Da for MS/MS data, allowing a maximum of one missed trypsin cleavage site and taking carbamidomethylation of cysteins and oxidation of methionines as variable modifications. Spectra were first searched for against a target-decoy version of a subset of the NCBInr database restricted to the bacteria found in 16S rRNA gene community analysis (see Results). Common contaminants (keratins and trypsin) were added to the database. Protein identification was confirmed when at least two peptides with high quality MS/MS spectra (less than 20 points below Mascot's threshold identity score at $95 \%$ confidence level) were detected. All spectra that did not satisfy these criteria were exported using Scaffold software program 2.2.0 (Proteome Software, Portland, USA) and used to search using the same database. Protein identification was confirmed when one peptide with a very high quality MS/MS spectrum (more than 5 points above Mascot's threshold identity score at $95 \%$ confidence level) was detected. After removing common contaminants, 
these thresholds led to protein identification with a false discovery rate of less than $3 \%$.

\section{Results}

\subsection{Chemical characterization of the sampling site}

The physico-chemical composition of sediment and water samples from the Gabe-Gottes mining site is shown in Table 1. The $\mathrm{pH}$ of the water was neutral. The low biological oxygen demand (BOD) and chemical oxygen demand (COD) values as well as the low amounts of suspended solids detected suggested that organic matter was not abundant in this water.

Table 1

Physical and chemical characteristics of water and sediment samples.

\begin{tabular}{|c|c|c|}
\hline & Water & Sediments \\
\hline \multicolumn{3}{|l|}{ General characteristics } \\
\hline $\mathrm{pH}$ & 6.9 & NT \\
\hline Density $\left(\mathrm{kg} \mathrm{1}^{-1}\right)$ & NT & 2.07 \\
\hline Moisture $20{ }^{\circ} \mathrm{C}(\%)$ & NT & 18 \\
\hline Moisture $105{ }^{\circ} \mathrm{C}(\%)$ & NT & 19.3 \\
\hline Fraction $<2 \mathrm{~mm}(\%)$ & NT & 57.8 \\
\hline Fraction $>2 \mathrm{~mm}(\%)$ & NT & 42.2 \\
\hline $\mathrm{OM}$ on $<2 \mathrm{~mm}(\%)$ & NT & 2 \\
\hline $\begin{array}{l}\text { Conductivity }\left(\mu \mathrm{S} \mathrm{cm} \mathrm{cm}^{-1}\right. \\
\left.\text { at } 25^{\circ} \mathrm{C}\right)\end{array}$ & 50.4 & NT \\
\hline Alkalinity (meq $1^{-1}$ ) & 0.18 & NT \\
\hline $\operatorname{TSS}\left(\mathrm{mg} \mathrm{l}^{-1}\right)$ & 0.7 & NT \\
\hline VSS & $100 \%$ & NT \\
\hline \multicolumn{3}{|l|}{ Chemical characteristics } \\
\hline $\begin{array}{l}\text { Total } \mathrm{P}\left(\mathrm{mg}^{-1} \text { in water; }\right. \\
\% \text { in sediments) }\end{array}$ & 0.03 & 0.08 \\
\hline $\mathrm{PO}_{4}\left(\mathrm{mg} \mathrm{P}^{-1}\right)$ & 0.02 & NT \\
\hline $\mathrm{COD}\left(\mathrm{mg} \mathrm{O}^{-1}\right)$ & 5 & NT \\
\hline $\mathrm{BOD} 5\left(\mathrm{mg} \mathrm{O} 1^{-1}\right)$ & 0.4 & NT \\
\hline $\mathrm{NH}_{4}\left(\mathrm{mg} \mathrm{N} 1^{-1}\right)$ & 0.02 & NT \\
\hline $\mathrm{NO}_{2}\left(\mathrm{mg} \mathrm{N}^{-1}\right)$ & $<0.01$ & NT \\
\hline $\mathrm{NO}_{3}\left(\mathrm{mg} \mathrm{N}^{-1}\right)$ & 1.2 & NT \\
\hline $\mathrm{TKN}\left(\mathrm{mg} \mathrm{N}^{-1}\right)$ & $<0.1$ & NT \\
\hline $\mathrm{Cl}^{-}\left(\mathrm{mg} \mathrm{l}^{-1}\right)$ & 2.1 & NT \\
\hline $\mathrm{SO}_{4}\left(\mathrm{mg} \mathrm{l}^{-1}\right)$ & 6.2 & NT \\
\hline $\mathrm{Br}\left(\mathrm{mg}^{-1}\right)$ & 0.004 & NT \\
\hline Chlo a $\left(\mu \mathrm{g} \mathrm{l}^{-1}\right)$ & 0.3 & NT \\
\hline Pheo $\left(\mu \mathrm{g}^{-1}\right)$ & 0.2 & NT \\
\hline \multicolumn{3}{|c|}{ Metals and metalloids ( $\mu \mathrm{g}^{-1}$ in water, $\mu \mathrm{g} \mathrm{g}^{-1}$ in sediments) } \\
\hline $\mathrm{Al}$ & 98 & 15150 \\
\hline As & 6 & $320^{\mathrm{a}}$ \\
\hline $\mathrm{Cd}$ & ND & 0.3 \\
\hline $\mathrm{Cr}$ & ND & 40 \\
\hline $\mathrm{Cu}$ & 1 & 103 \\
\hline $\mathrm{Fe}$ & ND & 23745 \\
\hline $\mathrm{Mn}$ & ND & 510 \\
\hline $\mathrm{Ni}$ & ND & 23 \\
\hline $\mathrm{Pb}$ & ND & 49 \\
\hline $\mathrm{Zn}$ & 2 & 88 \\
\hline
\end{tabular}

ND: not detected; NT: not tested; OM: organic matter; TKN: total Kjeldahl nitrogen; COD: chemical oxygen demand; BOD5: biological oxygen demand after 5 days; Chlo a: chlorophyll a; Pheo: pheophytine; TSS: total suspended solids; VSS: volatile suspended solids.

${ }^{a} \mathrm{As}(\mathrm{III})$ and $\mathrm{As}(\mathrm{V})$ concentrations measured in interstitial water were 14.6 and $135 \mu \mathrm{g} \mathrm{l}^{-1}$, respectively.
In addition, the organic content measured in the sediments themselves was only $2 \%$. Sulfate levels and water conductivity were also low, which suggest that ionic species were not abundant. The stream trophic state was assessed by measuring total nitrogen, phosphorus and chlorophyll content, which showed the presence of photosynthetic organisms (Dodds et al., 1998). Nitrogen and phosphorus compound contents were in the same range as levels detected in oligotrophic streams (<700 and $25 \mu \mathrm{g} 1^{-1}$, respectively) (Dodds et al., 1998). The chlorophyll a (Chlo a) content was lower in these samples than values found in mesotrophic streams (<10 $\mu \mathrm{g} \mathrm{l}^{-1}$ chlorophyll) (Dodds et al., 1998), which suggests that photosynthetic organisms were present but not very abundant. Based on these characteristics, this system was considered to be an oligotrophic ecosystem.

Concentrations of $\mathrm{Pb}, \mathrm{Al}$ and $\mathrm{Fe}$ in these sediment samples were 5, 190 and 500 times higher, respectively, than the average metal concentrations in the surrounding soils (http://www.stats.environnement.developpement-durable.gouv. fr/acces-thematique/sol/le-sol/la-contamination-des-sols-parles-elements-traces.html). Total arsenic contamination measured in the water column was lower $\left(6 \mu \mathrm{g} 1^{-1}\right)$ than the $10 \mu \mathrm{g} \mathrm{l}^{-1}$ limit recommended for drinking water. On the other hand, in sedimentary interstitial water, significantly higher $\mathrm{As}(\mathrm{III})$ and $\mathrm{As}(\mathrm{V})$ concentrations were measured (14.6 $( \pm 0.3) \mu \mathrm{g} 1^{-1}$ and $135( \pm 5) \mu \mathrm{g} 1^{-1}$, respectively), whereas none of the methylated forms searched for, i.e. DMA and MMA, were detected. The arsenic concentration observed in the sediment samples ( $320 \mathrm{mg} \mathrm{kg}^{-1}$ dry weight) was six times higher than the average geochemical content in this region (48 $\mathrm{mg} \mathrm{kg}^{-1}$ in the Vosges, http://infoterre.brgm.fr) and the $\mathrm{As}(\mathrm{V})$ species was 10 times more concentrated than the As(III) species. All in all, the physical and chemical characteristics determined here showed that this site contained neutral oligotrophic water with a moderately high level of heavy metal contamination.

\subsection{Structure of the prokaryote community in sediments based on $16 \mathrm{~S}$ rRNA genes}

An inventory of the whole bacterial and archaeal community was drawn up by performing $16 \mathrm{~S}$ rRNA-based community analysis. Total DNA extracted from the sediment was used as template for 16S rRNA gene amplification. Partial sequencing of 240 bacterial and 83 archaeal 16S rRNA genes and RPD analysis (see Materials and Methods) led to the identification of 193 and 20 OTUs (calculated with 97\% identity) belonging to 14 bacterial and 2 archaeal phyla, respectively. Concerning the bacterial library, rarefaction curves calculated at the class level (85\% identities) reached a plateau (Fig. 2). As the class level is the rank usually used for representing the bacterial community with less ambiguity, we limited our analysis to these clones, even though the rarefaction curves calculated at the species level ( $97 \%$ identity) did not reach a plateau. The rarefaction curves produced for archaeal sequence libraries reached a plateau which confirmed that the archaeal clone library was sufficiently sampled. 
The bacterial 16S rRNA gene sequences were found to be affiliated at the order, family or genus level, and considerable diversity was observed (Fig. 3). The bacterial community was composed mainly of Bacteroidetes (13\%), Betaproteobacteria (15\%), Acidobacteria (17\%) and Deltaproteobacteria (12\%). Several phyla, such as Alphaproteobacteria, Gammaproteobacteria, Actinobacteria, Nitrospira and Planctomycetes, accounted for $5-10 \%$ of the bacteria. Lastly, Firmicutes, Verrucomicrobia, Cyanobacteria, Gemmatimonadetes and Deinococcus/Thermus accounted for only a small proportion of the bacteria (less than 5\%) (Fig. 3). At the order level, Sphingobacteriales, Rhizobiales, Burkolderiales, Myxococcales and Planctomycetaceae were present. Interestingly, $12 \%$ of the clones were related to Acidobacteriaceae, the most abundant family. 14 clones amounting to $6 \%$ of the clones were related to the Nitrospira genus. This genus was therefore the most abundant one identified in this ecosystem. Lastly, 4 clones could not be definitively attributed to any known phylum, which suggests that unknown bacteria account for at least $1 \%$ of this community. Archaeal phylogenetic analysis (Fig. 4) showed that this population included Euryarchaeaota (29 clones, corresponding to $38 \%$ of the sample) and Thaumarchaeota (also known as group I Archaea) (DeLong, 1992; Fuhrman et al., 1992; Brochier-Armanet et al., 2008) (48 clones, corresponding to $62 \%$ of the sample). The Euryarchaeaota detected in this study site fell into four clusters (Fig. 4, I-IV), three of which (I-III) were found to be affiliated with methanogenic Archaea and were possibly from the anaerobic part of the sediment. One cluster (Fig. 4, IV) was more divergent and not closely related to any known species, but was affiliated with several $16 \mathrm{~S}$ rDNA clones previously reported (Rudolph et al., 2004; Galand et al., 2006). A large number of clones from Thaumarchaeota were also identified (Fig. 4). Three of them (clones 64 HQ664164, 19 HQ664132, 20 HQ664133) were affiliated with the species "Candidatus
Nitrososphaera gargensis", a moderately thermophilic Thaumarchaeon recently isolated from a terrestrial hot spring (Hatzenpichler et al., 2008). The others were affiliated with environmental sequences originating from the soil which likely represent uncultivated lineages of Thaumarchaeota (Sliwinski and Goodman, 2004; Nicol et al., 2006; ValenzuelaEncinas et al., 2008).

\subsection{Metaproteomic analysis}

Complementary to 16S RNA analysis, a metaproteomic approach was used to identify the main functional traits of the bacterial community. Microorganisms were separated from sediments and interstitial water by performing Nycodenz density gradient. An aliquot of these cells was stained with a live/dead BacLight kit (Invitrogen) and results showed that most cells extracted from the sediments were viable (data not shown). This finding showed that the gradient density-based bacterial recovery step did not affect cell membrane integrity. After SDS-PAGE electrophoresis, proteins were identified using an NCBInr database restricted to bacteria obtained with 16S rRNA-based community analysis (Table 2). Only 23 proteins were identified, half of them are involved in biological processes conserved within the prokaryotic kingdom, such as replication and transcription (elongation factors, transcriptional regulator), translation (ribosomal proteins), energy metabolism (ATP synthases), regulation (histone family, transcriptional regulator) and stress responses (Hsp90, GroEL). As these proteins are involved in widespread and highly conserved biological processes, they could be assigned to specific taxons. These proteins originated from Betaproteobacteria and Deltaproteobacteria, which were abundant in this community, as well as from Alphaproteobacteria, and Planctomycetes, each of which accounted for less than $10 \%$ of the community. Indeed, several of these proteins were

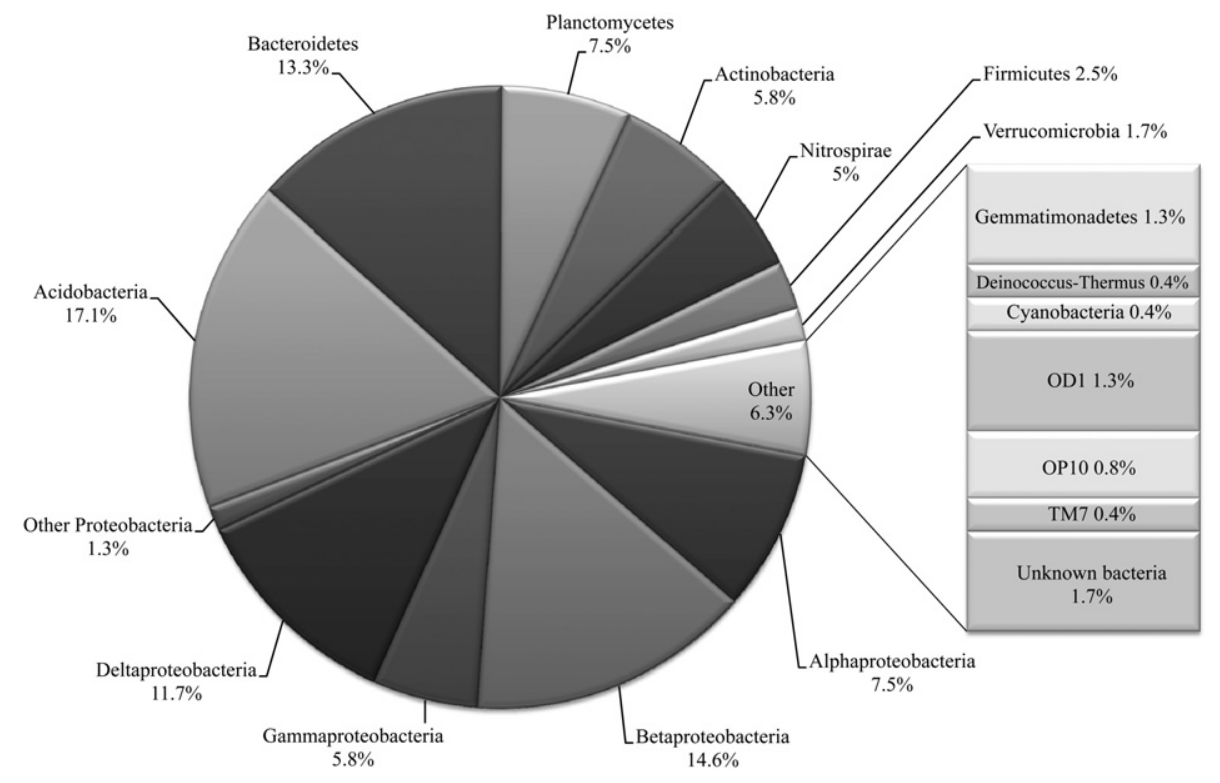

Fig. 3. Phylogenetic RDP affiliation of bacterial 16S rRNA genes (Class rank for Proteobacteria, phyla rank for the others). The most abundant phyla are shown in the circular diagram and the less abundant ones on the right. 


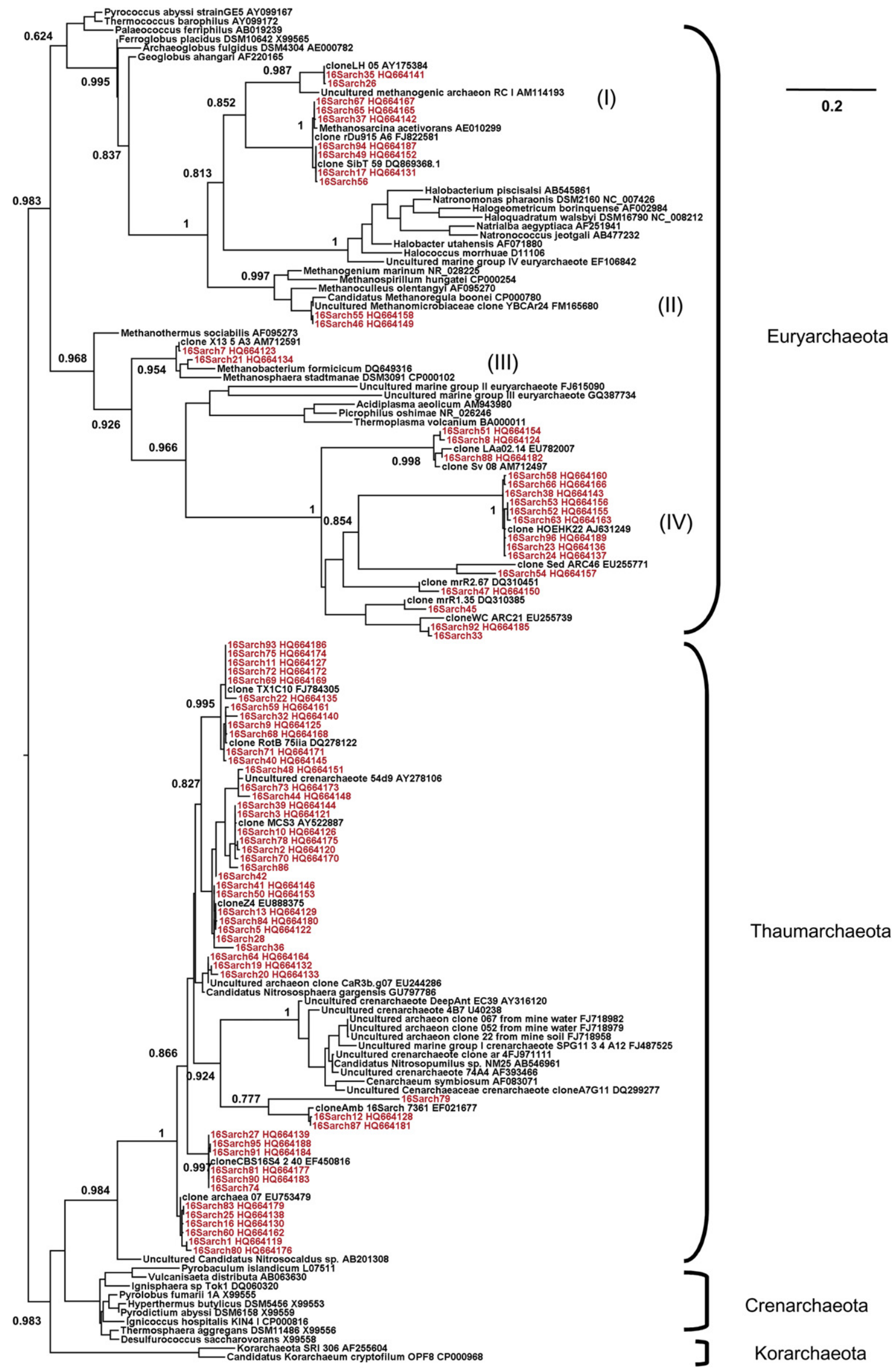

Fig. 4. Maximum likelihood tree of 16S rRNA gene homologs from the archaeal clones (in red font) along with a selection of representatives of archaeal diversity. The four main archaeal phyla are indicated. Numbers at nodes indicate aLTR (approximate likelihood-ratio test) branch support as computed by PhyML. The scale bar gives the average number of substitutions per site. 
expressed by bacteria affiliated with Hyphomicrobium, Parvimicrobium, Bradyrhizobium, Sphyngopyxis, Sideroxydans, Desulfovibrio and Planctomyces. The metaproteomic approach also revealed the presence of 6 proteins involved in the photosynthetic process and expressed by Cyanobacteria, although these photosynthetic bacteria accounted for less than $1 \%$ of the bacterial community.

\section{Discussion}

The aim of this study was to characterize, both chemically and microbiologically, a moderately arsenic-contaminated environment and to identify the arsenic-tolerant prokaryotic bacterial species. The bacterial and archaeal diversity observed at our study site is greater than that observed at other more severely contaminated sites (Baker and Banfield, 2003; Johnson and Hallberg, 2003), at the Carnoulès AMD, for example, where less than 10 phyla were identified (Bruneel et al., 2005, 2006, 2008) and in meta-genomic studies on AMD biofilm (4-6 bacterial species) (Tyson et al., 2004). Nor was such diversity observed in geothermal spring waters (6 phyla (Hamamura et al., 2009)).

This high level of diversity makes the meta-proteomic approach rather difficult to apply, which explains why only 23 proteins were identified despite efficient bacteria and protein extraction procedures. A low number of identified proteins was also observed previously in soil in which a high level of diversity was observed (Benndorf et al., 2007; Williams et al., 2010). As pointed out by the authors of recent reviews (VerBerkmoes et al., 2009; Denef et al., 2010), meta-proteomic studies are successful when applied to communities with low levels of diversity. When a high level of diversity is observed, each protein is diluted in a complex preparation and only the most abundant proteins are therefore likely to be identified. Moreover, a large proportion of the bacteria forming this community have never been studied thus far in vitro, and their genome sequences and hence their protein sequences, which are required for MS identification purposes, are not available in public databases. For example, contrary to Proteobacteria, only a few Acidobacteria protein sequences are available in the existing protein databases. Likewise, no archaeal proteins were identified, probably because only a few protein sequences of Archaea are available. On the other hand, the meta-proteomic approach has some advantages compared to other approaches. Indeed, as proteins are more stable than RNA (especially those originating from prokaryotes), the metaproteome content was presumed to be less affected by the extraction procedure than the transcriptome and probably gives better insight into the biological functions expressed in situ. Moreover, the meta-proteomic approach gives taxonomic information that was not observed with the $16 \mathrm{~S}$ rRNA gene-based approach. First, the diversity estimated with the 16S rRNA gene-based approach might be underestimated because of DNA extraction and PCR biases. Second, the metaproteomic approach highlights expression of proteins involved in conserved biological processes that could be assigned to a specific taxon at the genus or species level, whereas RDP analysis allowed us to affiliate only $28 \%$ at the genus level despite the use of almost all 16S rRNA gene sequence lengths. Such a limit was in agreement with previous observations establishing that it is not always possible to affiliate certain bacteria using only 16 S rRNA gene sequences (Schleifer, 2009). Indeed, some microorganisms showing very similar 16S rRNA gene sequences turned out to belong to different taxons when other phylogenetic markers were used. For these reasons, metaproteomic data provide a valid complementary tool for use with 16S rRNA gene-based taxonomy.

Several Thermoplasmatales related to our clones (Fig. 4, cluster IV) were previously identified in arsenic-rich environments such as that present in Carnoulès (Bruneel et al., 2008) as, for example, several Ferroplasma (Baker and Banfield, 2003; Denef et al., 2010). On the other hand, various Thaumarchaeota present here are affiliated with environmental sequences originating from soil (Sliwinski and Goodman, 2004; Nicol et al., 2006; Valenzuela-Encinas et al., 2008). To our knowledge, none of them have been previously observed in arsenic-contaminated environments. Concerning the bacterial phyla, Bacteroidetes have rarely been observed in arsenic-rich environments (except for a few Flavobacteria) (Honschopp et al., 1996), whereas other phyla detected here were previously described in arseniccontaminated samples, as for example Sideroxydans, Rhodoferax, Variovorax, Flavobacterium and Microbacterium (Baker and Banfield, 2003; Macur et al., 2004; Bruneel et al., 2006, 2011; Casiot et al., 2006; Achour et al., 2007; Achour-Rokbani et al., 2010). Such bacteria could impact arsenic speciation in this studied site. Bacteria related to Sideroxydans lithotrophicus were active in this ecosystem, as revealed by the metaproteomic approach. Such microorganisms are known to be preferentially present in a low oxygen concentration environment where they efficiently oxidize iron and may consequently have an indirect impact on the soluble arsenic concentration. Indeed, Fe(III) produced by these bacteria may co-precipitate with arsenate, leading to a decrease in soluble arsenite. Similarly, other species belonging to Rhodoferax are known to reduce iron under anaerobic conditions; their metabolism may therefore lead to an increased concentration of soluble arsenic compounds. Finally, some Betaproteobacteria identified using our proteogenomic approach may directly change arsenic speciation. Indeed, Variovorax sp. are arsenic-resistant bacteria known to reduce arsenate (Rathinasabapathi et al., 2006) and bacteria related to Flavobacterium were shown to methylate arsenic (Honschopp et al., 1996). Since arsenic was mainly found in an oxidized form (AsV) in this environment, it is tempting to speculate that both arsenic reduction and methylation activities were not important, in contrast to oxidation activity. Although we cannot exclude that abiotic processes also influence speciation of arsenic in this environment, arsenite oxidation may be catalyzed by bacteria affiliated with Microbacterium, as previously shown (Mokashi and Paknikar, 2002). Finally, other bacteria may also play a significant role in the functioning of this ecosystem. Identification of proteins originating from Plantomycetes, Cyanobacteria and Proteobacteria such as Rhizobiales revealed that these bacteria were not only present, but also viable, and physiologically active despite their low abundance, as suggested by the $16 \mathrm{~S}$ rDNA metagenomic approach (less than $5 \%$ of the bacterial 
Table 2

Main proteins expressed by the community.

\begin{tabular}{|c|c|c|c|c|c|c|c|}
\hline Phylum & Class & $\begin{array}{l}\text { Order; family; } \\
\text { genus; species }\end{array}$ & Protein name & $\begin{array}{l}\text { Protein } \\
\text { molecular } \\
\text { weight (Da) }\end{array}$ & $\begin{array}{l}\text { Number } \\
\text { of unique } \\
\text { peptides }\end{array}$ & $\begin{array}{l}\text { Percentage } \\
\text { sequence } \\
\text { coverage }(\%)\end{array}$ & $\begin{array}{l}\text { Peptide } \\
\text { sequence }\end{array}$ \\
\hline \multirow[t]{13}{*}{ Proteobacteria } & Unknown & Unknown & Thioredoxin & 11540.5 & 1 & 8.33 & GIPTLILFK \\
\hline & Alphaproteobacteria & $\begin{array}{l}\text { Rhodobacterales } \\
\text { or Rhizobiales }\end{array}$ & $\mathrm{F}_{0} \mathrm{~F}_{1}$-ATP synthase subunit beta & 51052.6 & 3 & 7.97 & $\begin{array}{l}\text { FTQAGSEV } \\
\text { SALLGR } \\
\text { IGLFGG } \\
\text { AGVGK } \\
\text { TVLIMELI } \\
\text { NNVAK }\end{array}$ \\
\hline & & & Pyrrolo-quinoline quinone & 65645.4 & 1 & 1.82 & $\begin{array}{l}\text { VAWTF } \\
\text { STGVLR }\end{array}$ \\
\hline & & $\begin{array}{l}\text { Rhizobiales; } \\
\text { Hyphomicrobiaceae; } \\
\text { Hyphomicrobium; } \\
\text { Hyphomicrobium } \\
\text { denitrificans }\end{array}$ & Conserved hypothetical protein & 21210.5 & 2 & 4.35 & $\begin{array}{l}\text { GPVSLPR } \\
\text { RGPVSLPR }\end{array}$ \\
\hline & & $\begin{array}{l}\text { Rhizobiales; } \\
\text { Phyllobacteriaceae; } \\
\text { Parvibaculum; } \\
\text { Parvibaculum }\end{array}$ & $\begin{array}{l}\text { Histone family protein } \\
\text { DNA-binding protein } \\
\text { 30S Ribosomal protein S4 }\end{array}$ & $\begin{array}{l}12014.1 \\
23808.7\end{array}$ & 2 & 16.80 & $\begin{array}{l}\text { LTGLGILQVR } \\
\text { NPATGEAIK } \\
\text { LSDYGVQLR }\end{array}$ \\
\hline & & $\begin{array}{l}\text { Rhizobiales; } \\
\text { Bradyrhizobiaceae; } \\
\text { Bradyrhizobium }\end{array}$ & Heat shock protein 90 & 68916.8 & 1 & 2.24 & $\begin{array}{l}\text { GVIDSEDL } \\
\text { PLNISR }\end{array}$ \\
\hline & & $\begin{array}{l}\text { Sphingomonadales; } \\
\text { Sphingomonadaceae; } \\
\text { Sphingopyxis }\end{array}$ & $\begin{array}{l}\text { 30S Ribosomal protein S3 } \\
\text { 30S Ribosomal protein S12 }\end{array}$ & $\begin{array}{l}27155.2 \\
13973.1\end{array}$ & $\begin{array}{l}1 \\
1\end{array}$ & $\begin{array}{l}3.32 \\
6.50\end{array}$ & $\begin{array}{l}\text { LGGAEIAR } \\
\text { PTINQLVR }\end{array}$ \\
\hline & Betaproteobacteria & $\begin{array}{l}\text { Gallionellales; } \\
\text { Gallionellaceae; } \\
\text { Sideroxydans; } \\
\text { Sideroxydans } \\
\text { lithotrophicus ES-1 }\end{array}$ & Chaperonin GroEL & 57287.8 & 2 & 7.85 & $\begin{array}{l}\text { AAVEEGIVPG } \\
\text { GGVALLR } \\
\text { AGRPLLIIAE } \\
\text { DVDGEALA } \\
\text { TLVVNNIR }\end{array}$ \\
\hline & & $\begin{array}{l}\text { Burkholderiales; } \\
\text { Comamonadaceae }\end{array}$ & Elongation Factor $\mathrm{Tu}$ & 43021.5 & 1 & 3.28 & $\begin{array}{l}\text { QVGVPYII } \\
\text { VFLNK }\end{array}$ \\
\hline & & & Enolase & 45992.7 & 2 & 5.61 & $\begin{array}{l}\text { AAAEES } \\
\text { GLPLYR } \\
\text { AAVPSG } \\
\text { ASTGSR }\end{array}$ \\
\hline & & & $\begin{array}{l}\text { 5-Methyl-tetrahydro-pteroyl- } \\
\text { triglutamate/homocysteine } \\
\text { S-methyltransferase }\end{array}$ & 86464.0 & 1 & 1.28 & VLSIGIVDGR \\
\hline & & & $50 \mathrm{~S}$ ribosomal protein $\mathrm{L} 2$ & 30162.6 & 1 & 4.01 & $\begin{array}{l}\text { SAGTSAT } \\
\text { LLAR }\end{array}$ \\
\hline & Deltaproteobacteria & $\begin{array}{l}\text { Desulfovibrionales; } \\
\text { Desulfovibrionaceae; } \\
\text { Desulfovibrio; } \\
\text { Desulfovibrio } \\
\text { salexigens }\end{array}$ & $\begin{array}{l}\text { Periplasmic binding protein/ } \\
\text { LacI transcriptional regulator }\end{array}$ & 30060.5 & 1 & 4.81 & $\begin{array}{l}\text { VIQLEGLA } \\
\text { GTSAAR }\end{array}$ \\
\hline $\begin{array}{l}\text { Cyanobacteria } \\
\text { or Firmicutes }\end{array}$ & Unknown & Unknown & Elongation Factor $\mathrm{Tu}$ & 43262.6 & 1 & 3.28 & $\begin{array}{l}\text { TTLTAAITT } \\
\text { VLAK }\end{array}$ \\
\hline
\end{tabular}


Table 2 (continued)

\begin{tabular}{|c|c|c|c|c|c|c|c|}
\hline Phylum & Class & $\begin{array}{l}\text { Order; family; } \\
\text { genus; species }\end{array}$ & Protein name & $\begin{array}{l}\text { Protein } \\
\text { molecular } \\
\text { weight (Da) }\end{array}$ & $\begin{array}{l}\text { Number } \\
\text { of unique } \\
\text { peptides }\end{array}$ & $\begin{array}{l}\text { Percentage } \\
\text { sequence } \\
\text { coverage }(\%)\end{array}$ & $\begin{array}{l}\text { Peptide } \\
\text { sequence }\end{array}$ \\
\hline \multirow[t]{7}{*}{ Cyanobacteria } & \multirow[t]{5}{*}{ Unknown } & \multirow[t]{5}{*}{ Unknown } & $\begin{array}{l}\text { Photosystem II reaction centre } \\
\text { protein PsbD/D2 }\end{array}$ & 39443.4 & 2 & 5.40 & AYDFVSQELR \\
\hline & & & & & & & NILLNEGIR \\
\hline & & & Photosystem $\mathrm{Q}(\mathrm{B})$ protein 1 & 29295.2 & 2 & 8.68 & $\begin{array}{l}\text { LIFQYAS } \\
\text { FNNSR }\end{array}$ \\
\hline & & & & & & & VINTWADIINR \\
\hline & & & Allophycocyanin alpha chain & 17413.2 & 2 & 11.80 & $\begin{array}{l}\text { SIVNADAEAR } \\
\text { YLSPGELDR }\end{array}$ \\
\hline & Chroococcales & Synechococcus & Hypothetical protein S7335_4928 & 7758.3 & 1 & 10.30 & LATVVTPR \\
\hline & Nostocales & Nostocaceae & $\begin{array}{l}\text { Photosystem Q(B) protein } 1 \text { ( } 32 \\
\text { KDa thylakoid membrane protein } 1) \text {; } \\
\text { Photosystem II } \\
\text { protein D1 }\end{array}$ & 39531.8 & 1 & 6.39 & $\begin{array}{l}\text { TIDTWAD } \\
\text { LLNR }\end{array}$ \\
\hline \multirow[t]{2}{*}{ Planctomycetes } & \multirow[t]{2}{*}{ Planctomycetacia } & $\begin{array}{l}\text { Planctomycetales; } \\
\text { Planctomycetaceae; } \\
\text { Planctomyces; } \\
\text { Planctomyces } \\
\text { limnophilus }\end{array}$ & $\begin{array}{l}\text { ATP synthase F1 subcomplex } \\
\text { beta subunit }\end{array}$ & 51974.8 & 2 & 4.99 & $\begin{array}{l}\text { FSQAGSEV } \\
\text { SALLGR } \\
\text { TVILQELIAR }\end{array}$ \\
\hline & & $\begin{array}{l}\text { Planctomycetales; } \\
\text { Planctomycetaceae; } \\
\text { Planctomyces; } \\
\text { Planctomyces maris }\end{array}$ & $\mathrm{F}_{0} \mathrm{~F}_{1}$-ATP synthase subunit beta & 52729.3 & $\begin{array}{l}1 \\
1\end{array}$ & 4.97 & $\begin{array}{l}\text { TVILTELIAR } \\
\text { FSQAGSEVS } \\
\text { ALLGR }\end{array}$ \\
\hline
\end{tabular}

clones). As Cyanobacteria and Rhizobiales are known to be involved in carbon and nitrogen fixation, these organisms could play an important role in such oligotrophic ecosystems.

In conclusion, by combining proteomic and genomic approaches in a mildly arsenic-contaminated environment, the diversity of arsenic-adapted prokaryotic communities was enlarged. Such approaches can thus serve to explore the diversity and the main functional traits of a bacterial community, including those having a high level of diversity.

\section{Acknowledgments}

Audrey Cordi was supported by grants from the French Ministry of Research and the "Zone Atelier Moselle" (ZAM) project. Audrey Heinrich-Salmeron, David Halter and Sebastien Gallien were supported by grants from the French Ministry of Research and the Universite de Strasbourg. Florence Goulhen-Chollet was supported by the Agence Nationale de la Recherche (ANR), RARE project (Reactivity of an Arsenic-Rich Ecosystem). This study was financed by the EC2CO program (Institut National des Sciences de l'Univers, CNRS) and BRG. This work was performed in the framework of the Groupement de Recherche "Métabolisme de l'Arsenic chez les micro-organismes: de la résistance à la détoxication" (GDR2909-CNRS).

\section{References}

Achour-Rokbani, A., Cordi, A., Poupin, P., Bauda, P., Billard, P., 2010. Characterization of the ars gene cluster from extremely arsenic-resistant Microbacterium sp. strain A33. Appl. Environ. Microbiol. 76, 948-955.
Achour, A.R., Bauda, P., Billard, P., 2007. Diversity of arsenite transporter genes from arsenic-resistant soil bacteria. Res. Microbiol. 158, 128-137. AFNOR, 1994. Qualité de l'Eau, seconde ed Paris.

Altschul, S.F., Madden, T.L., Schaffer, A.A., Zhang, J., Zhang, Z., Miller, W., Lipman, D.J., 1997. Gapped BLAST and PSI-BLAST: a new generation of protein database search programs. Nucl. Acids Res. 25, 3389-3402.

Anisimova, M., Gascuel, O., 2006. Approximate likelihood-ratio test for branches: a fast, accurate, and powerful alternative. Syst. Biol. 55, 539-552.

Ashelford, K.E., Chuzhanova, N.A., Fry, J.C., Jones, A.J., Weightman, A.J., 2005. At least 1 in 20 16S rRNA sequence records currently held in public repositories is estimated to contain substantial anomalies. Appl. Environ. Microbiol. 71, 7724-7736.

Baker, B.J., Banfield, J.F., 2003. Microbial communities in acid mine drainage. FEMS Microbiol. Ecol. 44, 139-152.

Benndorf, D., Balcke, G.U., Harms, H., von Bergen, M., 2007. Functional metaproteome analysis of protein extracts from contaminated soil and groundwater. ISME J. 1, 224-234.

Bertin, P.N., Médigue, C., Normand, P., 2008. Advances in environmental genomics: towards an integrated view of micro-organisms and ecosystems. Microbiology 154, 347-359.

Brochier-Armanet, C., Boussau, B., Gribaldo, S., Forterre, P., 2008. Mesophilic Crenarchaeota: proposal for a third archaeal phylum, the Thaumarchaeota. Nat. Rev. Microbiol. 6, 245-252.

Bruneel, O., Duran, R., Casiot, C., Elbaz-Poulichet, F., Personné, J.C., 2006. Diversity of microorganisms in $\mathrm{Fe}-$ As-rich acid mine drainage waters of Carnoules, France. Appl. Environ. Microbiol. 72, 551-556.

Bruneel, O., Duran, R., Koffi, K., Casiot, C., Fourçans, A., Elbaz-Poulichet, F., Personné, J.C., 2005. Microbial diversity in a pyrite-rich tailings impoundment (Carnoulès, France). Geomicrobiol. J. 22, 249-257.

Bruneel, O., Pascault, N., Egal, M., Bancon-Montigny, C., Goni-Urriza, M.S., Elbaz-Poulichet, F., Personné, J.C., Duran, R., 2008. Archaeal diversity in a Fe-As rich acid mine drainage at Carnoules (France). Extremophiles 12, $563-571$.

Bruneel, O., Volant, A., Gallien, S., Chaumande, B., Casiot, C., Carapito, C., Bardil, A., Morin, G., Brown Jr., G.E., Personné, J.C., Le Paslier, D., Schaeffer, C., Van Dorsselaer, A., Bertin, P.N., Elbaz-Poulichet, F., ArsènePloetze, F., 2011. Characterization of the active bacterial community involved 
in natural attenuation processes in arsenic-rich creek sediments. Microb. Ecol 61, 793-810.

Casiot, C., Pedron, V., Bruneel, O., Duran, R., Personne, J.C., Grapin, G., Drakides, C., Elbaz-Poulichet, F., 2006. A new bacterial strain mediating As oxidation in the Fe-rich biofilm naturally growing in a groundwater $\mathrm{Fe}$ treatment pilot unit. Chemosphere 64, 492-496.

Cole, J.R., Wang, Q., Cardenas, E., Fish, J., Chai, B., Farris, R.J., Kulam-SyedMohideen, A.S., McGarrell, D.M., Marsh, T., Garrity, G.M., Tiedje, J.M., 2009. The Ribosomal Database Project: improved alignments and new tools for rRNA analysis. Nucl. Acids Res. 37, D141-D145.

Coupland, K., Battaglia-Brunet, F., Hallberg, K.B., Dictor, M.C., Garrido, F., Johnson, D.B., 2004. Oxidation of iron, sulfur and arsenic in mine waters and mine wastes: an important role of novel Thiomonas spp. In: Tsezos, A. H.M., Remondaki, E. (Eds.), Biohydrometallurgy: A Sustainable Technology in Evolution. National Technical University of Athens, Zografou, Greece, pp. 639-646.

DeLong, E.F., 1992. Archaea in coastal marine environments. Proc. Natl. Acad. Sci. U S A 89, 5685-5689.

Denef, V.J., Mueller, R.S., Banfield, J.F., 2010. AMD biofilms: using model communities to study microbial evolution and ecological complexity in nature. ISME J. 4, 599-610.

Dodds, W.K., Jones, J.R., Welch, E.B., 1998. Suggested classification of stream trophic state: distributions of temperate stream types by chlorophyll, total nitrogen, and phosphorus. Water Res. 32, 1455-1462.

Edgar, R.C., 2004. MUSCLE: multiple sequence alignment with high accuracy and high throughput. Nucl. Acids Res. 32, 1792-1797.

Fuhrman, J.A., McCallum, K., Davis, A.A., 1992. Novel major archaebacterial group from marine plankton. Nature 356, 148-149.

Galand, P.E., Lovejoy, C., Vincent, W.F., 2006. Remarkably diverse and contrasting archaeal communities in a large arctic river and the coastal Arctic Ocean. Aquat. Microb. Ecol. 44, 115-126.

Guindon, S., Gascuel, O., 2003. A simple, fast, and accurate algorithm to estimate large phylogenies by maximum likelihood. Syst. Biol. 52, 696-704.

Hallberg, K.B., Johnson, D.B., 2005. Microbiology of a wetland ecosystem constructed to remediate mine drainage from a heavy metal mine. Sci. Total Environ. 338, 53-66.

Hamamura, N., Macur, R.E., Korf, S., Ackerman, G., Taylor, W.P., Kozubal, M., Reysenbach, A.L., Inskeep, W.P., 2009. Linking microbial oxidation of arsenic with detection and phylogenetic analysis of arsenite oxidase genes in diverse geothermal environments. Environ. Microbiol. 11, 421-431.

Hatzenpichler, R., Lebedeva, E.V., Spieck, E., Stoecker, K., Richter, A., Daims, H., Wagner, M., 2008. A moderately thermophilic ammoniaoxidizing crenarchaeote from a hot spring. Proc. Natl. Acad. Sci. U S A 105, 2134-2139.

Honschopp, S., Brunken, N., Nehrhorn, A., Breunig, H.J., 1996. Isolation and characterization of a new arsenic methylating bacterium from soil. Microbiol. Res. 151, 37-41.

Johnson, D.B., Hallberg, K.B., 2003. The microbiology of acidic mine waters. Res. Microbiol. 154, 466-473.

Laemmli, U.K., 1970. Cleavage of structural proteins during the assembly of the head of bacteriophage T4. Nature 227, 680-685.

Lièvremont, D., Bertin, P.N., Lett, M.C., 2009. Arsenic in contaminated waters: biogeochemical cycle, microbial metabolism and biotreatment processes. Biochimie 91, 1229-1237.

Macur, R.E., Jackson, C.R., Botero, L.M., McDermott, T.R., Inskeep, W.P., 2004. Bacterial populations associated with the oxidation and reduction of arsenic in an unsaturated soil. Environ. Sci. Technol. 38, 104-111.

Mandal, B.K., Suzuki, K.T., 2002. Arsenic round the world: a review. Talanta 58, 201-235.

Mokashi, S.A., Paknikar, K.M., 2002. Arsenic (III) oxidizing Microbacterium lacticum and its use in the treatment of arsenic contaminated groundwater. Lett. Appl. Microbiol. 34, 258-262.
Mueller, R.S., Denef, V.J., Kalnejais, L.H., Suttle, K.B., Thomas, B.C., Wilmes, P., Smith, R.L., Nordstrom, D.K., McCleskey, R.B., Shah, M.B., Verberkmoes, N.C., Hettich, R.L., Banfield, J.F., 2010. Ecological distribution and population physiology defined by proteomics in a natural microbial community. Mol. Syst. Biol. 6, 374.

Nicol, G.W., Tscherko, D., Chang, L., Hammesfahr, U., Prosser, J.I., 2006. Crenarchaeal community assembly and microdiversity in developing soils at two sites associated with deglaciation. Environ. Microbiol. 8, 1382-1393.

Raskin, L., Stromley, J.M., Rittmann, B.E., Stahl, D.A., 1994. Group-specific 16S rRNA hybridization probes to describe natural communities of methanogens. Appl. Environ. Microbiol. 60, 1232-1240.

Rathinasabapathi, B., Raman, S.B., Kertulis, G., Ma, L., 2006. Arsenicresistant proteobacterium from the phyllosphere of arsenichyperaccumulating fern (Pteris vittata L.) reduces arsenate to arsenite. Can. J. Microbiol. 52, 695-700.

Rudolph, C., Moissl, C., Henneberger, R., Huber, R., 2004. Ecology and microbial structures of archaeal/bacterial strings-of-pearls communities and archaeal relatives thriving in cold sulfidic springs. FEMS Microbiol. Ecol. 50, 1-11.

Schleifer, K.H., 2009. Classification of Bacteria and Archaea: past, present and future. Syst. Appl. Microbiol. 32, 533-542.

Schloss, P.D., Handelsman, J., 2005. Introducing DOTUR, a computer program for defining operational taxonomic units and estimating species richness. Appl. Environ. Microbiol. 71, 1501-1506.

Sharma, V.K., Sohn, M., 2009. Aquatic arsenic: toxicity, speciation, transformations, and remediation. Environ. Int. 35, 743-759.

Sliwinski, M.K., Goodman, R.M., 2004. Spatial heterogeneity of crenarchaeal assemblages within mesophilic soil ecosystems as revealed by PCR-singlestranded conformation polymorphism profiling. Appl. Environ. Microbiol. $70,1811-1820$.

Smedley, P.L., Kinniburgh, D.G., 2002. A review of the source, behaviour and distribution of arsenic in natural waters. Appl. Geochem. 17, 517-568.

Stahl, D.A., Amann, R., 1991. Development and application of nucleic acid probes. In: Stackebrandt, E., Goodfellow, M. (Eds.), Nucleic Acid Techniques in Bacterial Systematics. John Wiley \& Sons Inc., New York, pp. 205-248.

Thomas, P., Finnie, J.K., Williams, J.G., 1997. Feasibility of identification and monitoring of arsenic species in soil and sediment samples by coupled high-performance liquid chromatography - inductively coupled plasma mass spectrometry. J. Anal. Spectrom. 12, 1367-1372.

Thompson, J.D., Gibson, T.J., Higgins, D.G., 2002. Multiple Sequence Alignment Using ClustalW and ClustalX. Curr. Protoc. Bioinformatics Chapter 2, Unit 23.

Tsai, S.L., Singh, S., Chen, W., 2009. Arsenic metabolism by microbes in nature and the impact on arsenic remediation. Curr. Opin. Biotechnol. 20, 659-667.

Tyson, G.W., Chapman, J., Hugenholtz, P., Allen, E.E., Ram, R.J., Richardson, P.M., Solovyev, V.V., Rubin, E.M., Rokhsar, D.S., Banfield, J. F., 2004. Community structure and metabolism through reconstruction of microbial genomes from the environment. Nature 428, 37-43.

Valenzuela-Encinas, C., Neria-Gonzalez, I., Alcantara-Hernandez, R.J., Enriquez-Aragon, J.A., Estrada-Alvarado, I., Hernandez-Rodriguez, C., Dendooven, L., Marsch, R., 2008. Phylogenetic analysis of the archaeal community in an alkaline-saline soil of the former lake Texcoco (Mexico). Extremophiles 12, 247-254.

VerBerkmoes, N.C., Denef, V.J., Hettich, R.L., Banfield, J.F., 2009. Systems biology: functional analysis of natural microbial consortia using community proteomics. Nat. Rev. Microbiol. 7, 196-205.

Weiss, S., Carapito, C., Cleiss, J., Koechler, S., Turlin, E., Coppee, J.Y., Heymann, M., Kugler, V., Stauffert, M., Cruveiller, S., Médigue, C., Van Dorsselaer, A., Bertin, P.N., Arsène-Ploetze, F., 2009. Enhanced structural and functional genome elucidation of the arsenite-oxidizing strain Herminiimonas arsenicoxydans by proteomics data. Biochimie 91, 192-203.

Williams, T.A., Codoner, F.M., Toft, C., Fares, M.A., 2010. Two chaperonin systems in bacterial genomes with distinct ecological roles. Trends Genet. 26, 47-51. 